\title{
Improved selection of the functional unit in environmental impact assessment of cement
}

Alexis Sagastume Gutiérrez ${ }^{1}$, Juan J. Cabello Eras ${ }^{1}$, Carlos A. Gaviria ${ }^{2}$, Jo Van Caneghem ${ }^{3}$, Carlo Vandecasteele ${ }^{4}$

1: Universidad de la Costa. Calle 50 No 55-66. PBX 33622 00. Barranquilla. Colombia.

2: Programa de Ingeniería Civil, Facultad de Estudios a Distancia, Universidad Militar Nueva Granada, Carrera 11 No 101 80. Bogotá., Colombia.

3: Materials Technology TC, Campus Group T Leuven, Andreas Vesaliusstraat 13 - box 2600

4: Department of Chemical Engineering, University of Leuven, Celestijnenlaan 200F, 3001 Leuven, Belgium

\section{Abstract:}

The outcome of Life Cycle Assessment (LCA) studies is strongly influenced by the selection of the functional unit, which must be defined in such a way that, when products are compared, the amounts compared have identical utilities. LCA studies of cements mostly use mass based functional units (MFU). However, since different cements have a different composition and binding capacity, they result in different compressive strength and durability in their applications, so that MFUs are inadequate. Therefore, this study introduces as functional unit the Cement Functional Performance (CFP): mass of cement needed to obtain $1 \mathrm{MPa}$ of compressive strength during one year of durability (kg/(MPa·year)). To evaluate the effect of the CFP, the environmental performance of three cements is compared. Results show that adding $5 \%$ of zeolite to cement results in a similar strength and 1.78 times higher durability of the produced concrete, which is explained by the reduction of chloride diffusion. Moreover, adding $19 \%$ of zeolite to cement increases its durability 2.75 times, but reduces compressive strength by $29 \%$. As a result, cement with 5 and $19 \%$ of zeolite added has respectively 54 and $36 \%$ of the environmental impacts of Portland cement.

Keywords: Life cycle assessment, functional unit, cement, environmental impact Nomenclature:

A - Acidification potential

D - Durability (years)

$A D$ - Abiotic depletion

E - Eutrophication

ADP - Abiotic depletion of fossil fuel

FU - Functional unit

$\mathrm{BC}-$ Blended cements

GHG - Greenhouse gases

bi - Binder intensity

GWP - Global warming potential

CFP - Cement functional performance

HT - Human toxicity

CS -28 days compressive strength of concrete

LCA - Life cycle assessment 
LCIA - Life cycle impact assessment

ME - Marine ecotoxicity

MFU - Mass based functional unit

$\mathrm{m}$ - Mass of binder $(\mathrm{kg})$

ODP - Ozone depletion potential

P-35 - Zeolite blended cement (5\% of zeolite)

PC - Portland cement

PO - Photochemical oxidation

PP-25 - Zeolite blended cement (19\% of

zeolite)

SG - Strength grade of cement

VC-Volume of concrete $\left(\mathrm{m}^{3}\right)$ 


\section{Introduction}

Cement, is one of the most important construction materials commercialized worldwide (Chen et al., 2015), and is essential in the construction and maintenance of buildings and infrastructure (Rodrigues and Joekes, 2011). Cement is an energy, carbon and material intensive product (Jamin and Mahmood, 2015) and accounts for 5 to $7 \%$ of the global emissions of $\mathrm{CO}_{2}$ (Cheng et al., 2010 ) and for 12 to15 \% of the total energy consumed in industry worldwide (Madlool et al., 2011). Furthermore, cement production is projected to increase yearly by 0.8 to $1.2 \%$ (Stafford et al., 2016 ). Emission of $\mathrm{CO}_{2}$, the main actor of climate change, is one of the main environmental threads of today (Benhelal et al., 2012; Valipuor et al., 2017). Climate change and global warming, among others, raised the public awareness on the environmental impact of the cement industry, and led to the introduction of legislations and incentives to regulate and reduce greenhouse gas (GHG) emissions (Imbabi, 2012). In addition, cement production causes also other environmental impacts than the GHG emissions (e.g. gaseous emissions impacting the acidification potential or human toxicity among others).

Two general approaches can be identified to reduce the environmental impact of cements: (1) at factory level (production phase), to reduce the specific emissions of cement production and (2) at construction sites (consumption phase), to reduce cement consumption. Portland cement (PC), which dominates the world market (Ammenberg et al., 2015), accounts for 74 to $81 \%$ of the $\mathrm{CO}_{2}$ emissions of concrete production (Flower and Sajayan, 2007) and contributes to most of the other environmental impacts (Sjunnesson, 2005). Thus, the partial replacement of clinker by cementing materials in the production of cements and concretes is almost unavoidable. This results in the production of blended cements (BCs), defined as cements where some clinker has been replaced by cementing materials. This may result in energy savings and may reduce $\mathrm{CO}_{2}$ emissions (Uzal et al., 2010). However, little information is available on the specificities of the production of new cements, and it is also rarely subjected to independent unbiased evaluations, mainly because of commercial constraints and patenting issues (Gartner and Mcphee, 2011). The barriers faced by BCs, such as regulatory restrictions, slow adaptation of standards and reluctance to use materials with less well understood properties (Gursel et al., 2014; Ammenberg et al., 2015), cause that, in spite of the environmental benefits of BCs as compared to PC (Huntzinger and Eatmon, 2009; Chen et al., 2015), the latter still dominates the market (Ammenberg et al., 2015). Furthermore, the amount of waste that can be used as cementing material in BCs is limited (Damineli et al., 2010). In China, which accounts for around 60\% of the global cement production, PC represents $95-98 \%$ 
of the total production (Wang et al., 2014; Chen et al., 2015); in the United States PC accounts for 97 \% of the overall production, although cementing materials are frequently added during concrete mixing (Gursel et al., 2014). In Europe 70\% of the commercialized cements are blended, partly as a consequence of emission restrictions imposed by the Kyoto protocol (Gursel et al., 2014).

Cement is used as the binding agent in concretes and mortars and its primary function is to develop strength and durability in its applications. The physical and chemical properties of cement influence both the compressive strength and durability of the resulting concretes (Gartner and Mcphee, 2011). Durability rather than compressive strength is the most important characteristic of concretes, although both are closely related (Aitcin, 2000), and it is considered essential in the evaluation of concretes (Van den Heede and De Belie, 2012). Moreover, Benhelal et al. (2013) pointed out that, although using alternative materials as clinker substitute can reduce $\mathrm{CO}_{2}$ emissions, it also impacts the strength development of cement over time. Thus, the introduction of alternatives to clinker requires further research to guarantee the properties of cement (García-Gusano et al., 2015).

Several studies discuss the LCA of cement production in different countries as shown in Table 1.

Table 1. LCA studies of cement production

Results show that several studies identified clinker production (in rotary kilns) as the main pollution source in cement production. Furthermore, the impacts in some impact categories like $M E, A D$ and PO are allocated to activities outside the cement plant, as the production of inputs like gypsum and electricity (Chen et al., 2010). The use of alternative fuels and raw materials (mainly alternatives to clinker) is frequently suggested to reduce the environmental impacts of cement production.

In most studies, mass-based functional units (MFU) are used, although Li et al., (2015) and Damineli et al. (2010) showed that taking into account the strength of cements in the FU influences the results of the LCA study. In most cases, a unit mass of cement is not a true substitute of a unit mass of another cement, as it does not take into account the primary functions of cement, which depend on both the compressive strength (that depends on its binder capacity) and durability resulting from cement applications (e.g. concrete) (Aitcin 2000; Lippiatt and Ahmad, 2004; Gurcel et al., 2014). On mass-basis, cements with less clinker will always show lower environmental impacts, although lower strength or durability may be obtained, so that more cement is required to achieve the same results. Therefore, some doubts on the real environmental performance of cements 
arise when one considers that most LCA studies of cement production use MFUs. Consequently, it is important to take into account the primary functions of cement (i.e. the compressive strength and durability resulting from applications like concrete) to assess and compare its environmental performance. This will contribute to the actual need to support markets for BCs, focusing more on cement properties than on cement composition (Feiz et al. 2015a; 2015b; Ammenberg et al., 2015).

The inconsistencies of MFU to assess cements and concretes have already been pointed out (Lippiatt and Ahmad, 2004), stressing the need to consider certain properties like compressive strength, unit weight, permeability, workability, durability and thermal conductivity for a meaningful comparison (Gursel et al., 2014).

Damineli et al. (2010), consider the influence of the compressive strength by introducing the bi, which is the ratio between the mass of cement used per cubic meter of concrete and the 28 days compressive strength obtained. Results show a high dispersion on the properties of the concretes assessed, resulting in different compressive strengths for the same mass $\left(\mathrm{kg} / \mathrm{m}^{3}\right)$ of binder, proving that other factors (like cement composition) influence the results, thus demonstrating the inadequacy of MFUs to describe the functional performance of cements and concretes. However, durability is not considered in the functionalities of cement in this case. Considering the importance of durability on the functionalities of concrete, De Schepper et al. (2014) in an LCA study of recyclable concretes, used the amount of concrete $\left(\mathrm{m}^{3}\right)$ needed to obtain 1 MPa of compressive strength and 1 year of durability as FU ( $\left.\mathrm{m}^{3} /(\mathrm{MPa} \cdot \mathrm{year})\right)$. However, this study assessed the environmental performance of concrete (use phase of cements), which aside from cement includes other construction materials. Conclusions thus point to the use of one or another construction material (e.g. use PC or BC) in the concrete mix, rather than specific measures in cement production. Therefore, given the significance of durability in the properties of the cement applications, its introduction in the LCA of cements (production phase) seems like a logical step towards a more comprehensive assessment of cement production.

This study aims at introducing a new FU that considers the influence of the cement mix on the environmental impacts of its production phase. To this end the new FU includes the functionalities of cement, namely the compressive strength and the durability resulting from the application of cement in concretes. The new FU is used to assess the life cycle impact assessment (LCIA) of three cements, which are also assessed based on a MFU and the bi. The LCIAs based on the three FUs are compared. 


\section{Materials and methods.}

This study follows the guidelines of ISO 14040 (ISO, 2006) to implement the LCA. LCA allows to improve production processes (Sagastume et al., 2012) and may also support the process of decision-making (Li et al., 2014). In general, full scale LCA studies are complicated and time consuming (Feiz et al., 2015a). Therefore, most LCA studies of cement production are frequently simplified to cradle-to-gate approaches, using a unit mass of cement or clinker as FU (Cankaya and Pekey, 2015). Only Damineli et al. (2010) and Li et al. (2015) considered some functionality of cement by including the compressive strength in their assessments. No study so far considered the durability of cement applications on its functionalities.

Three cements, produced in "Cementos Cienfuegos S.A. (Galvez, 2012; Lafont, 2016)", are assessed in this study to compare the FUs used in literature to the proposed FU.

\subsection{Functional unit.}

The definition of the FU is one of the most influential factors in the outcome of an LCA study (Van den Heede and De Belie, 2012; Gursel, 2014; Cankaya and Pekey, 2015), and its inadequate selection leads to wrong conclusions (Matheys et al., 2007). The FU describes the primary function(s) of a product (Guinée et al., 2001) and must be defined so that the products compared are true substitutes for one another (Lippiatt and Ahmad, 2004). Consequently, it is very important to consider both the durability and compressive strength when cements or concretes are assessed (Aitcin, 2000).

Damineli et al. (2010) proposed the bi as FU for LCA studies of cement.

$\mathrm{bi}=\frac{\mathrm{m}}{\mathrm{VC} \cdot \mathrm{CS}}$

However, only one functionality of cement is considered (i.e. the 28 days compressive strength of concrete).

This study proposes a new FU, following the approach of Damineli et al., (2010) of using a ratio between the mass of binder and the cement functionalities. In this case, the FU is thus defined as the mass of binder (kg) per MPa of compressive strength and per year of durability (kg.MPa ${ }^{1}$.year $\left.{ }^{-1}\right)$ of the concrete end product, and, as it takes the functional performance of cements into account, it will be referred to as the Cement Functional Performance (CFP) unit: 


$$
\mathrm{CFP}=\frac{\mathrm{m}}{\mathrm{CS} \cdot \mathrm{D}}
$$

Cements that result in concretes with the highest compressive strength and durability for the lowest mass of binder has obviously the lowest CFP.

\subsection{Durability of reinforced concrete}

As concrete production consumes about 70\% of the cement produced (Portland Cement Association: http://www.cement.org/for-concrete-bookslearning/cement-manufacturing), concrete mixtures are used to define the durability of cements in this study. The durability of reinforced concrete is a measure of its resistance to weathering actions, chemical attacks, abrasion, etc. while maintaining its properties. The primary degradation factors with long-term effects on the structural capacity of concrete elements are: corrosion of reinforcement bars due to chloride penetration and/or carbonation, mechanical abrasion, surface deterioration, salt weathering, and frost attack (Sarja, 2000). In general, corrosion due to chloride is the main degradation factor of the reinforcement bars (Gjørv, 2014). Consequently, the time until the end of life of concrete structures due to chloride corrosion of the reinforcement bars (which depends on ambient exposure such as temperature, humidity and on concrete characteristics such as chloride diffusivity) is considered as durability in this study.

To estimate the durability of reinforced concrete, the probabilistic analysis method of the time to the first corrosion of the reinforcement bars, which is based on the modified Fick second law of diffusion (Bentz, 2003), is used. This method is included in the software Life-365 (Bentz and Thomas, 2015), which is used in this study.

This method, requires experimental data to calculate the change of the apparent chloride diffusivity $\left(D_{\text {app }}\right)$ over time $(t)$ :

$\mathrm{D}_{\text {app }}(\mathrm{t})=\mathrm{D}_{\mathrm{ref}} \cdot\left[\frac{\mathrm{t}_{\mathrm{ref}}}{\mathrm{t}}\right]^{\mathrm{m}} \quad\left(\frac{\mathrm{m}^{2}}{\mathrm{~s}}\right)$

where the initial chloride diffusivity ( $D_{\text {ref }}$ ) of concretes at the reference time $t_{\text {ref, }}$ usually 28 days (Ann et al., 2009), and the diffusion decay index (m) (a constant that accounts for the rate of decay of $D_{\text {app }}$ due to the continued hydration of concrete over time, which in turn depends on the composition of the concrete) are experimentally measured.

Since durability depends on ambient exposure and concrete characteristics, comparing different cements on the same basis requires definition of these parameters. An average concrete cover (i.e. the smallest distance between the surface of the embedded reinforcement and the outer surface 
of concrete) of $70 \mathrm{~mm}$ (generally used in environments with chloride presence) is considered. Moderate environmental loads (i.e. a maximum chloride concentration on the surface of concrete of $1.5 \%$ of the mass of the cement used in concrete) are considered, as suggested by Browne et al. (1980) and Gjørv (2014). To account for the effects of temperature a mean value of $30^{\circ} \mathrm{C}$ is used. It is additionally considered that no barriers (membrane or sealant application) are used to extend concrete life, and that hydration of the binder material is completed after 25 years. Finally, traditional carbon steel is considered for the reinforcements in this research.

A number of experimental studies measured the chloride diffusivity of concretes with up to $30 \%$ of zeolite replacing PC (Chan and Ji, 1999 ; Ahmadi and Shekarchi, 2010; Ramezanianpour et al., 2013; Dousti et al., 2013; Valipour et al., 2013a; Valipour et al., 2013b; Sabet et al., 2013; Valipour et al., 2014). However, only Valipour et al. (2013a) measured $D_{\text {ref }}$ following the standards indicated in Bentz (2003) (see Table 2), as required for the probabilistic analysis method. These values are used to estimate concrete durability.

Table 2. Chloride diffusivity of concretes with a varying $\%$ of zeolite for $w / b=0.4$ (Valipuor et al., 2013a).

To the best of our knowledge, no study exists of the influence of zeolite on $\mathrm{m}$. To estimate $\mathrm{m}$, the Rapid Chloride Permeability Test (RCPT) results reported by Ramezanianpour et al. (2013) for concretes with up to $30 \%$ of zeolite for different time periods, are used. The RCPT measures the total electric charge (in Coulomb), obtained from passing electrical current through a cylindrical concrete specimen (100 mm of diameter and $50 \mathrm{~mm}$ width) when a potential difference of $60 \mathrm{~V}$ is maintained across the specimen for $6 \mathrm{~h}$ (Ramezanianpour et al., 2013) . The RCPT provides a rapid indicator of the resistance to chloride ion penetration. Results of the RCPT are equivalent to chloride diffusivity (Thomas and Jones, 1996; Bjegović et al., 2016):

$\mathrm{D}=3 \cdot \mathrm{C} \cdot 10^{-15}\left(\frac{\mathrm{m}^{2}}{\mathrm{~s}}\right)$

where $\mathrm{C}$ stands for the Coulombs resulting from the RCPT. Table 3 shows the progress in time of the chloride diffusivity for the concretes discussed by Ramezanianpour et al. (2013).

Table 3. Chloride penetration and diffusivity of concretes with zeolite 
The diffusion decay index $(\mathrm{m})$ is the slope of the linear fit for the logarithmic relation between $\mathrm{D}$ and $\mathrm{t}$ (Bamforth, 1999). Fig. 1 shows the linear regression for concretes containing $20 \%$ of zeolite.

Fig. 1. Variation of diffusivity over time (20\% zeolite sample)

The values of $m$ for the zeolite fractions discussed in Table 3 are shown in Table 4.

Table 4. $m$ value for concretes with different zeolite fractions

Taking $\mathrm{m}=0.2$ for PC (Bentz and Thomas, 2015), $\mathrm{m}$ can be obtained for different zeolite fractions (see Fig. 2). Adding other cementing materials like fly ash and slag, results in a linear increment of $m$ (Bentz and Thomas, 2015). Similarly, Fig. 2 shows that $m$ increases linearly with the addition of zeolite.

Fig. 2. Variation of $m$ with the zeolite fraction ( $m$ : from Table 4)

The values of $D_{\text {ref }}$ and $m$ to calculate the durability of the concretes assessed in this study, and the results obtained are shown in Table 6 .

\subsection{Concrete mix design}

Concrete mixtures are mainly composed of cement, aggregates, water, reinforcements and in some cases may contain other cementing materials and/or chemical admixtures ( $\mathrm{ACl} 211.1$, 2009). The strength and other mechanical and chemical properties (e.g. the chloride diffusivity) of concrete mixtures are affected by the composition of the binder used (i.e. cement, pozzolans, etc.) (Najimi et al., 2012). Concrete properties are specially affected by the presence of pozzolans, usually used to enhance properties like the strength development, permeability to aggressive solutions, etc. ( $\mathrm{ACl}$ 211.1, 2009; ACl 225R, 2009). In particular, the strength grade of cements represents the 28 days compression strength of hydraulic cement mortar cubes of standardized dimensions and cement-sand mix (Oficina Nacional de Normalización, 2013). The strength grade of cements is used as indicator for its selection for concrete mixtures. Nevertheless, it is possible to obtain compressive strengths higher than the strength grade of the cement used in a concrete mix, if superplasticizers are used to reduce the water/binder ratio. As the use of superplasticizers is difficult and costly (Kumar, 1999), it is recommended to use cements with a strength grade higher or equal to the desired compressive strength. Therefore, in this study concrete mixtures are designed with a compressive strength equal to the strength grade of the cements assessed. 
The generalized method used to design concrete mixtures is described in the Standard Practice for Selecting Proportions for Normal, Heavyweight, and Mass Concrete $(\mathrm{ACl} 211.1,2009)$ of the American Concrete Institute (ACl). This method estimates the proportion of each material for a particular mix, based on a target compression strength of concrete, the available size of fines and coarse aggregates and the chemical admixtures to be used in the mix.

The cements considered in this study are shown in Table 5.

Table 5. Characteristics of cements produced in "Cementos Cienfuegos S.A" (Galvez, 2012; Lafont, 2016)

*SG: strength grade of cement

Using the cements of Table 5, three concrete mixtures are designed based on the standard ACI 211.1 (2009), of the American Concrete Institute. Their properties are shown in Table 6. In the design of these concretes the same aggregates (i.e. fines and coarse aggregates with the same size) were considered.

Table 6. Design of concrete mix

From the results it appears that using cement with more zeolite added (see table 2) results in higher durability of the concrete. According to Valipour et al., 2014 the increase is limited to $20 \%$ of zeolite addition, whereafter durability starts decreasing. It must be mentioned that PP-25 results in almost 300 years of durability. However, there is a consensus that the life service of concrete structures is usually between 50 to 100 years (Aktas and Bilec, 2012; FIT, 2012). Consequently, in this study we set an upper limit of 100 years to the durability of concrete.

\subsection{Cement production}

Fig. 3. Process flow diagram of cement production.

In Fig. 3, Error! Reference source not found.raw material preparation (stage 1) includes quarrying of limestone, zeolite and other minerals, followed by crushing and grinding of raw materials and finally drying (using petcoke) and homogenizing of the raw meal (grinded raw materials). The grinded zeolite does not follow the same path of the raw meal, instead it is directly supplied to the mixing clinker and additives step (stage 3). The raw material preparation is followed by clinker production (stage 2), including preheating and precalcination of the raw meal and clinker production in the rotary kiln. This is the most energy intensive part of the cement production process where fuel (usually petcoke) is combusted in the rotary 
kiln to provide the necessary heat for clinker production. The hot gases leaving the kiln provide the thermal energy required by the precalciner and the preheater. Finally, the last stage (stage 3) involves grinding, mixing clinker and gypsum and/or other additives, and packaging.

The environmental impact of the production of three cements (Table 5) used for the production of concrete will be assessed, taking into account the durability and strength of the resulting concrete. Use will be made of the newly introduced functional unit and also of the MFU and the bi, and the results will be compared.

As described in fig. 1, the scope of this study comprises the cement production stages in a cradle-to-gate perspective. The functionalities of cement (i.e. strength and durability) are deduced from the properties of concrete mixtures designed with the cements under assessment.

Table 7 shows the FUs compared in this study.

Table 7. MFU, bi and CPF for the different cements

\subsection{Inventory analysis}

The inventory includes the inputs and emissions associated with the production, from stage 1 to stage 3 , of the amounts of PC, P-35 and PP- 25 corresponding to the functional unit. Additionally, the inputs and emissions resulting from the production of minerals used in cement production, like zeolite, marl and iron ore, are considered. Similarly to the limestone, these minerals are extracted from quarries in the vicinities of the cement plant considered (stage 1 in Fig. 1). The information used in the inventory was obtained directly from the cement plant (Galvez, 2012; Lafont, 2016). Table 8 shows the inventory for the different cements assessed. For the sake of comparison the inventory is presented on the basis of MFU and CFP. In this way, the inventory can be compared to other studies using MFUs. Furthermore, the implications of using either MFU or CFP can be discussed.

Wastes generated in the considered cement production plant include scrap metal, office wastes, wood and process materials (raw materials, clinker and cement). However, only around $123 \mathrm{t}$ /year of wastes are generated in total, corresponding to a few g per t of cement. Moreover, these wastes are partly recycled (i.e. scrap metals, paper from office wastes and wood) and the ones that are landfilled (i.e. wastes of raw materials and clinker and cement rejected because of low quality) have a limited environmental impact. Therefore these wastes are not included in the inventory. 
The life cycle inventories of producing petcoke, diesel, explosives and lubricants were taken from SIMAPRO 7.3, while the inventory for electricity is taken from (Sagastume et al., 2012).

Table 8. Inventory of cement production

From Table 8, it appears that the inventory per MFU is strongly influenced by the clinker fraction. PC has 5 and $19 \%$ more clinker than P-35 and PP25 respectively, which results in 4.6\% more emissions than P-35 and 13.2\% more emissions than PP-25. On the contrary, the inventory based on CFP has no proportionality to the clinker content: PC has $46.5 \%$ more emissions than P-35, while it results in $63.9 \%$ more emissions than PP-25.

\subsection{Life cycle impact assessment (LCIA)}

The environmental impacts in this study are assessed using the CML 2001 (problem oriented) method developed by the Institute of Environmental Sciences at the University of Leiden (“Centrum voor Milieutechnologie Leiden") (Guinée et al., 2002).

Cement production is mainly characterized by its energy intensity and by the direct emission of airborne pollutants (i.e. $\mathrm{CO}_{2}, \mathrm{CO}_{1}, \mathrm{SO}_{x}, \mathrm{NO}_{x}, \mathrm{PM} 10$, dioxins and furans and heavy metals). Therefore, to assess the environmental impacts of cement production this study considers the impact categories mainly affected by the emissions of the cement plant itself (direct impacts):

1. Abiotic depletion of fossil fuels (ADP): mainly affected by consumption of petcoke and electricity

2. Acidification (A): mainly affected by the emissions of $\mathrm{SO}_{x}$ and $\mathrm{NO}_{x}$

3. Global warming potential (GWP): mainly affected by the emissions of $\mathrm{CO}_{2}$ and $\mathrm{CO}$

4. Photochemical oxidation (PO): mainly affected by the emissions of $\mathrm{SO}_{\mathrm{x}}, \mathrm{CO}$ and $\mathrm{NOx}$

5. Eutrophication (E): mainly affected by the emissions of $\mathrm{NO}_{\mathrm{x}}$

6. Human toxicity (HT): mainly affected by the emissions of PM10, dioxins and furans, $\mathrm{SO}_{\mathrm{x}}$ and heavy metals

\section{Results}

In this section the environmental impacts of the three cements considered is assessed on the basis of MFU, bi and CFP. FU - Stands for either the bi $\left(\frac{\mathrm{kg}}{\mathrm{m}^{3} \cdot \mathrm{MPa}}\right)$ or the CFP $\left(\frac{\mathrm{kg}}{\mathrm{MPa} \cdot y e a r}\right)$. 
Table 9 shows the environmental impacts of the different cements per unit mass. Given that the bi and the CFP are a ratio of the mass of cement and its functionalities, and that the MFU accounts for the impacts of cement per unit of mass, the environmental impacts based on the bi and the CFP are calculated as the impacts based on the MFU multiplied by the bi or the CFP for each cement:

$\operatorname{Impact}(\mathrm{FU})=\operatorname{Impact}(\mathrm{MFU}) \cdot \mathrm{FU}$

where:

Impact(FU) - Stands for the environmental impacts based on either the bi or the CFP.

Impact(MFU) - Stands for the environmental impacts based on MFU.

FU - Stands for either the bi $\left(\frac{\mathrm{kg}}{\mathrm{m}^{3} \cdot \mathrm{MPa}}\right)$ or the CFP $\left(\frac{\mathrm{kg}}{\mathrm{MPa} \cdot y e a r}\right)$.

Table 9. LCIA of cement production (per kg of cement)

Fig. 4 shows the environmental impacts of the BCs as a fraction of the impacts of PC for the three FUs.

Fig. 4. Comparison of the LCIA results obtained for MFU, bi and CFP

Fig. 4 shows that when using a MFU the environmental impacts are directly proportional to the clinker fraction in cement. Moreover, based on bi the relative impacts of P-35 referred to PC remain unchanged as compared to the use of the MFU. This is because the bi has the same value for both PC and P-35 (see Table 7), as it is when the MFU is used. Additionally, PP-25 results in similar environmental impacts than PC, been the impacts slightly higher for two impact categories. This is explained by the lower compressive strength of PP-25, which result in a higher value of the bi than PC and P-35. Finally, based on the CFP, results show that P-35 and PP-25 have about 54 and $36 \%$ of the impacts of PC respectively. This is mostly explained because the use of PC results in 56 and $37 \%$ of the durability of P-35 and PP-25 respectively. In this case, the results of the assessment are more influenced by durability than by compressive strength, as durability varies more than compressive strength (i.e. from 36.4 to 100 years (a variation of $275 \%$ ) compared to a variation of 35 to $25 \mathrm{MPa}(29 \%)$ ).

To properly address the environmental impacts of cement production, it is necessary to allocate the impacts to the different stages of cement production, allowing to implement mitigating measures with the highest impacts. 
Fig. 5. Influence of inputs/emissions to the different impact categories for PC

Fig. 5 shows the main contributions of the inputs (i.e. indirect emissions associated with the production of inputs like petcoke, electricity, etc.) and emissions (i.e. direct emissions like $\mathrm{CO}_{2}, \mathrm{NO}_{x}, \mathrm{SO}_{x}$, etc.) to the impact categories considered for the production of PC. Inputs and emissions contributing with less than $5 \%$ are not included in figure.

Results show that petcoke consumption accounts for around $98 \%$ of the impacts on ADP, while electricity consumption and SOx emissions sum up to about $80 \%$ of the impacts on $\mathrm{A}$ and $78 \%$ of the impacts on $\mathrm{PO}$ from cement production. Moreover, $\mathrm{CO}_{2}$ emissions account for over $98 \%$ of the impacts on GWP, while NOx emissions account for around 15\% of the impact on A and around $86 \%$ of the impact on E. Results are similar for P-35 and PP-25.

Fig. 6 shows the contribution of the different stages to the different impact categories for the production of PC.

Fig. 6. Contribution of the cement production stages to each impact category (PC).

Results show that stage 2 (clinker production) accounts for most environmental impacts (60 to 95\%) in all the impact categories, while stages 1 and 3 account for less than $20 \%$ of the impacts each. In particular, stage 2 accounts for $96 \%$ of the impact on ADP (resulting from the consumption of petcoke), $64 \%$ of the impact on $\mathrm{A}$ (of which $27 \%$ result from the electricity consumption and 24 and $49 \%$ from the emissions of $\mathrm{NO}_{\mathrm{x}}$ and $\mathrm{SO}_{\mathrm{x}}$ respectively), $96 \%$ of the GWP (of which $46 \%$ result from the fuel combustion and $52 \%$ from the limestone calcination), $65 \%$ of the impacts on PO (of which $25 \%$ result from the electricity consumption and 48 and $27 \%$ from the emissions of $\mathrm{SO}_{\mathrm{x}}$ and CO respectively), $91 \%$ of the impacts on eutrophication (of which $97 \%$ result from the $\mathrm{NO}_{\mathrm{x}}$ emissions) and $94 \%$ of the impacts on $\mathrm{HT}$ (of which $89 \%$ result from the emissions of dioxins and furans). For P-35 and PP-25 results are similar. The environmental impacts of stage 2 are mostly related to either the fuel combustion or to the limestone calcination. Therefore, improving the thermal efficiency of clinker production has the highest potential to reduce the environmental impacts of cement production in Cementos Cienfuegos SA. Moreover, from the LCIA results it seems logical to increase the production of P-35 over PC and, where PP-25 can be used, to use it instead of PC and P-35.

\section{Discussion}


In agreement with other studies (Huntzinger and Eatmon, 2009), our LCA results show that when a MFU is used the environmental impacts are proportional to the clinker fraction: compared to PC (95\% of clinker), P-35 (90\% of clinker) results in an about 5\% lower impact, and PP-25 (76\% of clinker) in about 20\% lower impacts. Moreover, in agreement with Damineli et al. (2010), when the bi is used, cements with the highest strength grade and the lowest clinker content have the lowest impacts, which is explained with the higher mass of binder required to deliver one unit of functional performance (1 MPa of compressive strength) for lower compressive strength concretes. On the other hand, when the CFP is used, results show that less binder is required per unit of functional performance for the cements with higher zeolite fraction, which result in concrete mixes with higher durability. Therefore, since the environmental performance of cement, based on its functionalities is not proportional to the mass fraction of its major components (mainly clinker), MFUs are inadequate to assess cements within the LCA approach. Moreover, if durability is not considered on the cement functionalities, cements with the highest strength grade shows a better environmental performance. Durability, a main primary function of cement applications, is an indicator of the lifespan of concrete structures, and it is thus very important to assess the performance of cements (Aitcin, 2000). Results from Damineli et al. (2010) show that omitting durability on the FU can lead to the wrong conclusions, showing a relatively low environmental performance (i.e. the impacts of PP- 25 as compared to PC) for cements that actually perform better.

The importance of durability is highlighted by De Schepper et al. (2014), which compared 2 completely recyclable concretes with two PC concretes based on their functionalities. In this case, completely recyclable concretes (65.1 MPa and 81 and 63 years of durability), resulted in a lower environmental performance as compared to PC concrete (57.8 and 69.3 MPa and 100 years durability), mainly because of the higher durability considered for PC concretes. It is unclear how durability was defined in the study. In this case, the results pointing to PC as a better environmental choice as compared to the use of cementing materials, which differ from the results of this study. These results stresses the influence of the cement mix in the functionalities of cement applications (concrete in this case). Additionally, it stresses the significance of durability on cement functionalities.

Given the significance of durability to assess the environmental performance of cements and concretes, a clear approach is recommended for its assessment. 


\section{Conclusions}

Results of this study confirm that MFU are inadequate to effectively compare the environmental impact of different cements within the LCA approach. Moreover, the use of the binder intensity as functional unit (that only considers the compressive strength of concrete as the primary function of cement) points to cements with the highest strength grade for a better environmental performance. On this basis, cements with the highest strength grade require less binder to obtain a unit of functional performance (i.e. one MPa of compressive strength). Finally, when considering both the strength and durability as the primary functions of cement, a better environmental performance than foreseen with mass based functional units and the binder intensity results from the assessment of zeolite blended cements. This is explained because the functionalities of cement depend on the properties of the cement mix, rather than on the mass fraction of its components, and when using zeolite BCs less binder is required to obtain a unit of functional performance compared to the use of PC.

Since the CFP considers the main functionalities of cement, it allows a more objective environmental comparison of different cements. These results point to increase the production of P-35 and if possible to replace PC. Additionally, results point to the use of PP-25 over PC and P-35 in applications demanding a lower compressive strength.

\section{References}

ACl 211.1, 2009 Standard Practice for Selecting Proportions for Normal, Heavyweight, and Mass Concrete. American Concrete Institute, 38pp.

$\mathrm{ACl} 225 \mathrm{R}, 2009$. Guide to the Selection and Use of Hydraulic Cements. American Concrete Institute, 30pp.

Ahmadi, B., Shekarchi, M., 2010. Use of natural zeolite as a supplementary cementitious material. Cement and Concrete Composites. 32, 134141.

Aitcin, P.C., 2000. Cements of yesterday and today. Concrete of tomorrow. Cement and Concrete Research. 30, 1349-1359.

Ammenberg, J., Baas, L., Eklund. M., Feiz, R., Helgstrand, A., Marshall. R., 2015. Improving the CO2 performance of cement, part III: the relevance of industrial symbiosis and how to measure its impact. Journal of Cleaner Production. 98, 145-155.

ASTM C150/C150M-15, Standard Specification for Portland Cement, ASTM International, West Conshohocken, Pa, USA, 2016 
Benhelal, E., Zahedi, G., Shamsaei, E., Bahadori. A., 2013. Global strategies and potentials to curb CO2 emissions in cement industry. Journal of Cleaner Production. 51, 142-161.

Benhelal, E., Zahedi, Hashim, H., 2012. A novel design for green and economical cement manufacturing. Journal of Cleaner Production. 22, 6066.

Bentz, E.C., Thomas, M.D.A., 2015. Life-360 service life prediction model, version 2.2.2. http://www.life-365.org/download.html Accessed: April, 2016.

Bjegović, D., Serdar, M., Oslaković, I. S., Jacobs, F., Beushausen, H., Andrade, C., Monteiro, A.V., Paulini, P., Nanukuttan, S., 2016. Test methods for concrete durability indicators. In Performance-Based Specifications and Control of Concrete Durability (pp. 51-105). Springer Netherlands.

Browne, R., 1980. Marine Durability Survey of the Tongue Sand Tower, Concrete in the Ocean Program, CIRIA UEG Technical Report 5. Cement and Concrete Association. London, England.

Cabello, J.J., Sagastume, A., Hernández D., Hens, L., Vandecasteele, C., 2013. Improving the environmental performance of an earthwork project using cleaner production strategies. Journal of Cleaner Production. 47, 368-376.

Cankaya, S., Pekey, B., 2015. Identifying environmental impacts of cement production with life cycle assessment: Literature review. Journal of International Scientific Publications. 9, 251-267.

Chan, S. Y., Ji, X., 1999. Comparative study of the initial surface absorption and chloride diffusion of high performance zeolite, silica fume and PFA concretes. Cement and Concrete Composites. 21, 293-300.

Chen, C., Habert, G., Bouzidi, Y., Jullien, A., 2010. Environmental impact of cement production: detail of the different processes and cement plant variability evaluation. Journal of Cleaner Production. 18, 478-485.

Chen, W., Hong, J., Xu, C., 2015. Pollutants generated by cement production in China, their impacts, and the potential for environmental improvement. Journal of Cleaner Production. 103, 61-69.

Damineli, B.L., Kemeid, F.M., Aguiar, P.S., John. V.M., 2010. Measuring the eco-efficiency of cement use. Cement \& Concrete Composites. 32, 555-562. 
De Schepper, M., Van den Heede, P., Van Driessche, I., De Belie, N., 2014. Life Cycle Assessment of Completely Recyclable Concrete. Materials. 7, 6010-6027.

Dousti, A., Rashetnia, R., Ahmadi, B., Shekarchi, M., 2013. Influence of exposure temperature on chloride diffusion in concretes incorporating silica fume or natural zeolite. Construction and Building Materials. 49, 393-399.

Feiz, R., Ammenberg, J., Baas, L., Eklund, M., Helgstrand, A., Marshall, R., 2015. Improving the CO2 performance of cement, part I: utilizing lifecycle assessment and key performance indicators to assess development within the cement industry. Journal of Cleaner Production. 98, 272-281.

Feiz, R., Ammenberg, J., Baas, L., Eklund, M., Helgstrand, A., Marshall, R., 2015. Improving the CO2 performance of cement, part II: framework for assessing $\mathrm{CO} 2$ improvement measures in the cement industry. Journal of Cleaner Production. 98, 282-291.

FIT, International Federation for Structural Concrete, 2012. Guidelines for green concrete structures: Guide to good practice Vol. 67, 60 pp.

Flower, D.J.M., Sanjayan, J.G., 2007. Greenhouse gas emissions due to concrete manufacture. The International Journal of Life Cycle Assessment. $12,282-288$.

Gabel, K., Tillman, A.M., 2005. Simulating operational alternatives for future cement production. Journal of Cleaner Production. 13, $1246-1257$.

Galvez, E., 2012. Mecanismo de desarrollo limpio para la disminución de las emisiones de CO2 en la producción de cementos con aditivos en Cementos Cienfuegos, S.A. Master thesis. Universidad de Cienfuegos, Cuba

García-Gusano, D., Herrera, I., Garraín, D., Lechón, Y., Caval, H., 2015. Life cycle assessment of the Spanish cement industry: implementation of environmental-friendly solutions. Clean Technologies and Environmental Policy. 17, 59-73.

Gartner, E.M., Macphee, D.E., 2011. A physico-chemical basis for novel cementitious binders. Cement and Concrete Research.41, 736-749.

Gjørv, O.E., 2014. Durability design of concrete structures in severe environments. CRC Press. Florida. US $254 \mathrm{p}$.

Guinée, J.B., Gorrée, M., Heijungs, R., Huppes, G., Kleijn, R., de Koning, A., van Oers, L., Sleeswijk, A.W., Suh, S., de Haes, H.A.U., de Bruijn, H., van Duin, R., Huibregts, M.A.J., 2001. Life cycle assessment: an operational guide to the ISO standards. Ministry of Housing, spatial Planning and the Environment and Center of Environmental Sciences - Leiden University. Leiden. The Netherlands. 
Gursel, A.P., Masanet, E., Horvath, A., Stadel,A., 2014. Life-cycle inventory analysis of concrete production: A critical review. Cement and Concrete Composites. 51, 38-48.

Hong, J., Li, X., 2011. Environmental assessment of sewage sludge as secondary raw material in cement production - A case study in China. Waste Management. 31, 1364-1371.

Huntzinger, D.N., Eatmon, T.D., 2009. A life-cycle assessment of Portland cement manufacturing: comparing the traditional process with alternative technologies. Journal of Cleaner Production. 17, 668-675.

Imbabi, M.S., Carrigan, C., McKenna, S., 2012. Trends and developments in green cement and concrete technology. International Journal of Sustainable Built Environment. 1, 194-216.

ISO 14040, 2006. Environmental Management-life Cycle Assessment Principles and Framework. International Organization for Standardization. Geneva. Switzerland.

Izaguirre, A., Lanas, J., Alvarez, J.I., 2010. Ageing of lime mortars with admixtures: Durability and strength assessment. Cement and Concrete Research. 40, 1081-1095.

Jamin, N.C., Mahmood, N.Z., 2015. Hazardous waste management in Malaysia: A case study on cement manufacturing. Procedia Environmental Sciences. DOI: 10.13140/RG.2.1.3646.2808.

Josa, A., Aguado, A., Cardim, A., Byars, E., 2007. Comparative analysis of the life cycle impact assessment of available cement inventories in the EU. Cement and Concrete Research. 37, 781-788.

Josa, A., Aguado, A., Heino, A., Byars, E., Cardim, A., 2004. Comparative analysis of available life cycle inventories of cement in the EU. Cement and Concrete Research. 34, 1313-1320.

Kartini, K., 2011. Rice husk ash-pozzolanic material for sustainability. International Journal of Applied Science and Technology. 1, 169-178.

Lafont, C.C., 2016. Análisis del ciclo de vida (ACV) de la producción de cemento cubano. Master thesis. Universidad de Cienfuegos, Cuba

Li, C., Cui, S., Nie, Z., Gong, X., Wang, Z., Itsubo, N., 2015. The LCA of Portland cement production in China. The International Journal of Life Cycle Assessment. 20, 117-127. 
Li, C., Nie, Z., Cui, S., Gong, X., Wang, Z., Meng. X., 2014. The life cycle inventory study of cement manufacture in China. Journal of Cleaner Production. 72, 204-211.

Lippiatt, B.C., Ahmad, S., 2004. Measuring the life-cycle environmental and economic performance of concrete: the BEES approach. In Proceedings of the International Workshop on Sustainable Development and Concrete Technology (pp. 213-230).

Madlool, N.A., Saidur, R., Hossain, M.S., Rahim, N.A., 2011. A critical review on energy use and savings in the cement industries. Renewable and Sustainable Energy Reviews. 15, 2042-2060.

Matheys, J., Van Autenboer, W., Timmermans, Van Mierlo. J-M., Van den Bossche, J., Maggetto, G., 2007. Influence of functional unit on the life cycle assessment of traction batteries. The International Journal of Life Cycle Assessment. 12, 191-196.

Najimi, M., Sobhani, J., Ahmadi, B., Shekarchi, M., 2012. An experimental study on durability properties of concrete containing zeolite as a highly reactive natural pozzolan. Construction and Building Materials. 35, 1023-1033.

Navia, R., Rivela, B., Lorber, K.E., Méndez, R., 2006. Recycling contaminated soil as alternative raw material in cement facilities: Life cycle assessment. Resources. Conservation and Recycling. 48, 339-356.

Nisbet, M., Van Geem, M.G., 1997. Environmental life cycle inventory of Portland cement and concrete. World Cement. 28, 3-5.

Oficina Nacional de Normalización, 2013. NC 506:2013. Cemento Hidráulico. Método de Ensayo. Determinación de la resistencia mecánica. Ciudad de La Habana, (Cuba).

Ramezanianpour, A. A., Kazemian, A., Sarvari, M., Ahmadi, B., 2013. Use of natural zeolite to produce self-consolidating concrete with low Portland cement content and high durability. Journal of Materials in Civil Engineering. 25, 589-596.

Rodrigues, F.A., Joekes, I., 2011. Cement industry: sustainability, challenges and perspectives. Environmental Chemistry Letters. 9, 151-166.

Sabet, F.A., Libre, N.A., Shekarchi, M., 2013. Mechanical and durability properties of self consolidating high performance concrete incorporating natural zeolite, silica fume and fly ash. Construction and Building Materials. 44, 175-184.

Sagastume, A., Van Caneghem, J., Cogollos, J.B., Vandecasteele, C., 2012. Evaluation of the environmental performance of lime production in Cuba. Journal of Cleaner Production. 31, 126-136. 
Sanchez, S., Favier, A., Domínguez, E.R., Sanchez, I.R., Heierli, U., Scrivener, K., Martirena, F., Habert, G., 2016. Assessing the environmental and economic potential of Limestone Calcined Clay Cement in Cuba. Journal of Cleaner Production. 124, 361-369.

Sarja, A., 2000. Durability design of concrete structures-Committee report 130-CSL. Materials and Structures. 33, 14-20.

Sjunnesson, J., 2005. Life Cycle Assessment of Concrete. Department of Technology and Society. Lund University. Master thesis.

Stafford, F.N., Dias, A.C., Arroja, L., Labrincha, J.A., Hotza, D., 2016. Life cycle assessment of the production of Portland cement: A Southern Europe case study. Journal of Cleaner Production. doi:10.1016/j.jclepro.2016.02.110

Strazza, C., Del Borghi, A., Gallo, M., Del Borghi, M., 2011. Resource productivity enhancement as means for promoting cleaner production: analysis of co-incineration in cement plants through a life cycle approach. Journal of cleaner production. 19, 1615-1621.

Thomas, M.D.A., Jones, M.R., 1996. A critical review of service life modelling of concretes exposed to chlorides. Concrete in the service of mankind: Radical Concrete Technology. 723-736.

Uzal, B., Turanli, L., Yücel, H., Göncüoğlu, M.C., Çulfaz, A., 2010. Pozzolanic activity of clinoptilolite: A comparative study with silica fume, fly ash and a non-zeolitic natural pozzolan. Cement and Concrete Research. 40, 398-404.

Valderrama, C., Granados, R., Cortina, J.L., Gasol, C.M., Guillem, M., Josa, A., 2012. Implementation of best available techniques in cement manufacturing: a life-cycle assessment study. Journal of Cleaner Production. 25, 60-67.

Valipour, M., Pargar, F., Shekarchi, M., Khani, S., 2013. Comparing a natural pozzolan, zeolite, to metakaolin and silica fume in terms of their effect on the durability characteristics of concrete: A laboratory study. Construction and Building Materials. 41, 879-888.

Valipour, M., Pargar, F., Shekarchi, M., Khani, S., Moradian, M., 2013. In situ study of chloride ingress in concretes containing natural zeolite, metakaolin and silica fume exposed to various exposure conditions in a harsh marine environment. Construction and Building Materials. 46, 6370.

Valipour, M., Sefidkouhi, M.A.G., Raeini, M., 2017. Selecting the best model to estimate potential evapotranspiration with respect to climate change and magnitudes of extreme events. Agricultural Water Management. 180, 50-60. 
Valipour, M., Yekkalar, M., Shekarchi, M., Panahi, S., 2014. Environmental assessment of green concrete containing natural zeolite on the global warming index in marine environments. Journal of Cleaner Production. 65, 418-423.

Van den Heede, P., De Belie, N., 2012. Environmental impact and life cycle assessment (LCA) of traditional and 'green' concretes: literature review and theoretical calculations. Cement and Concrete Composites. 34, 431-442.

Wang, Y., Höller, S., Viebahn, P., Hao, Z., 2014. Integrated assessment of CO2 reduction technologies in China's cement industry. International Journal of Greenhouse Gas Control. 20, 27-36.

Zabalza, I., Valero, A., Aranda, A., 2011. Life cycle assessment of building materials: comparative analysis of energy and environmental impacts and evaluation of the eco-efficiency improvement potential. Building and Environment. 46, 1133-1140. 


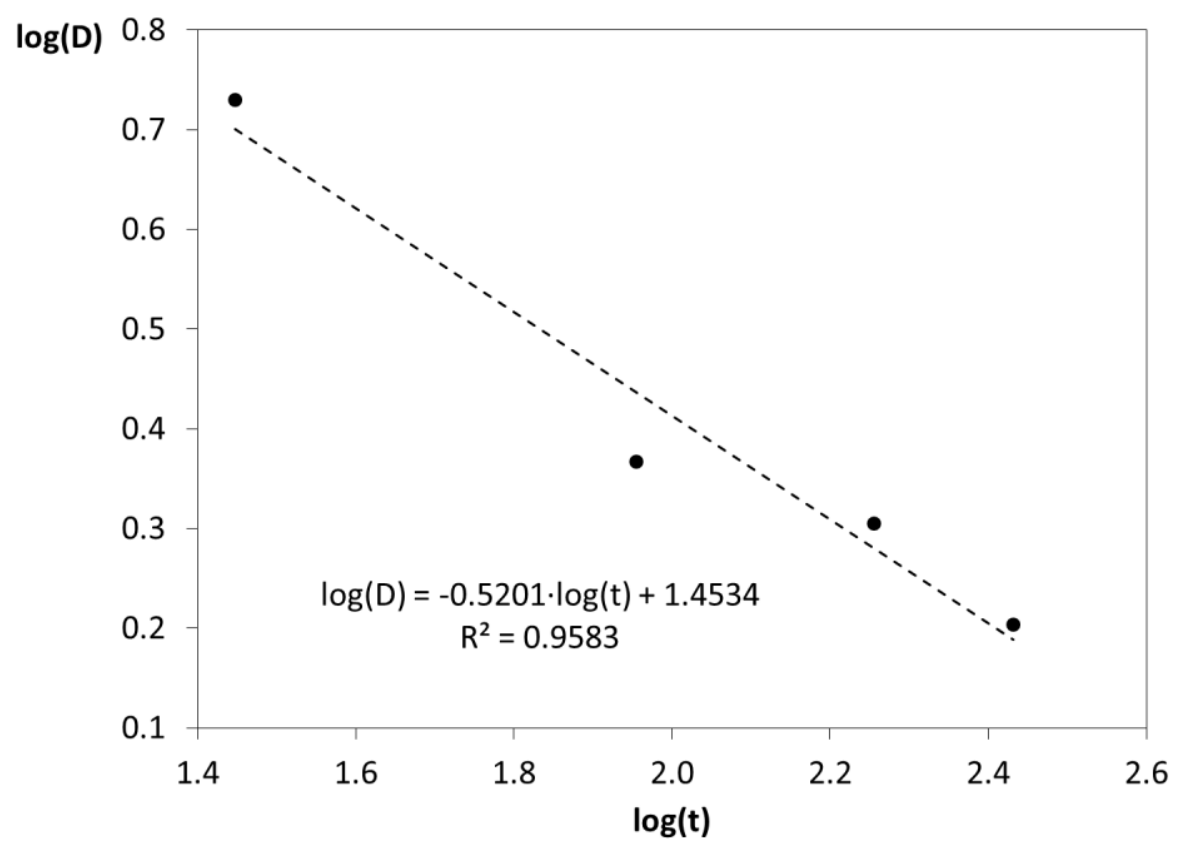

Fig. 7. Variation of diffusivity over time ( $20 \%$ zeolite sample) 


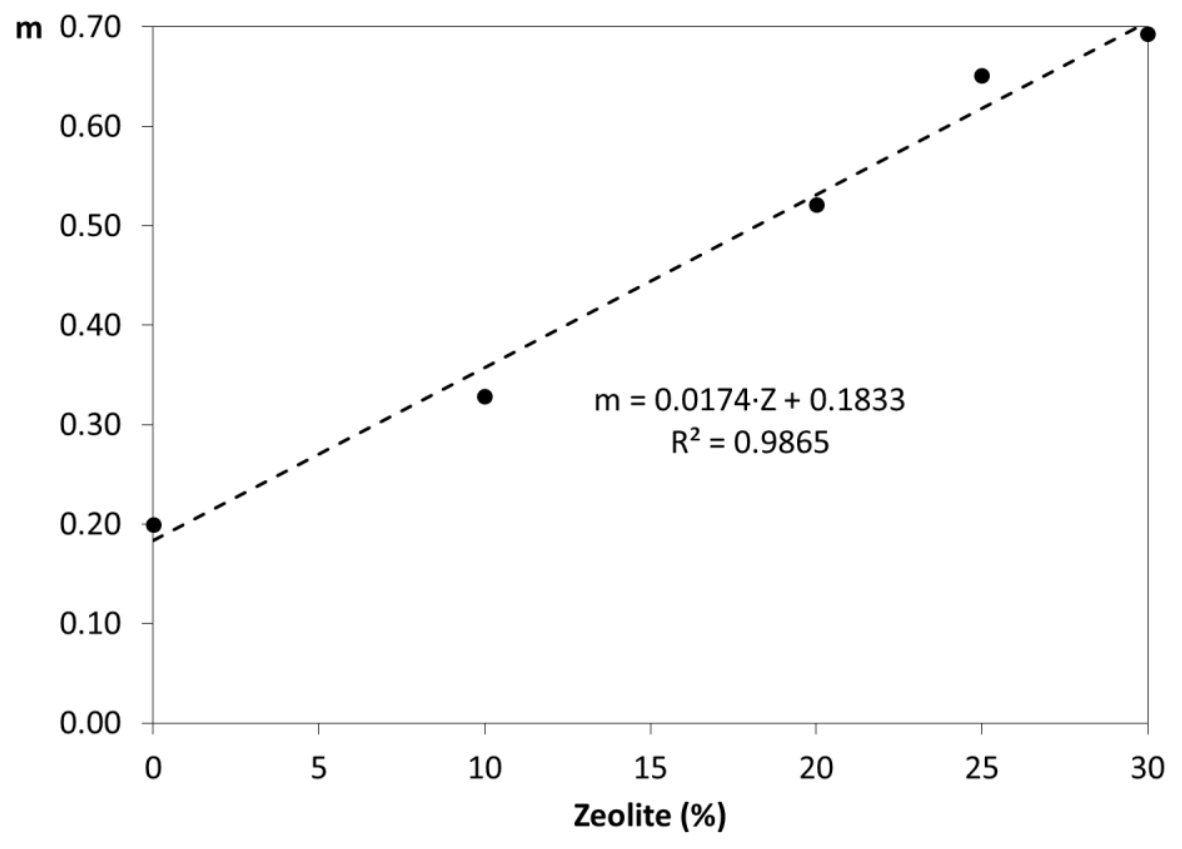

Fig. 8. Variation of $m$ with the zeolite fraction ( $m$ : from Table 4) 


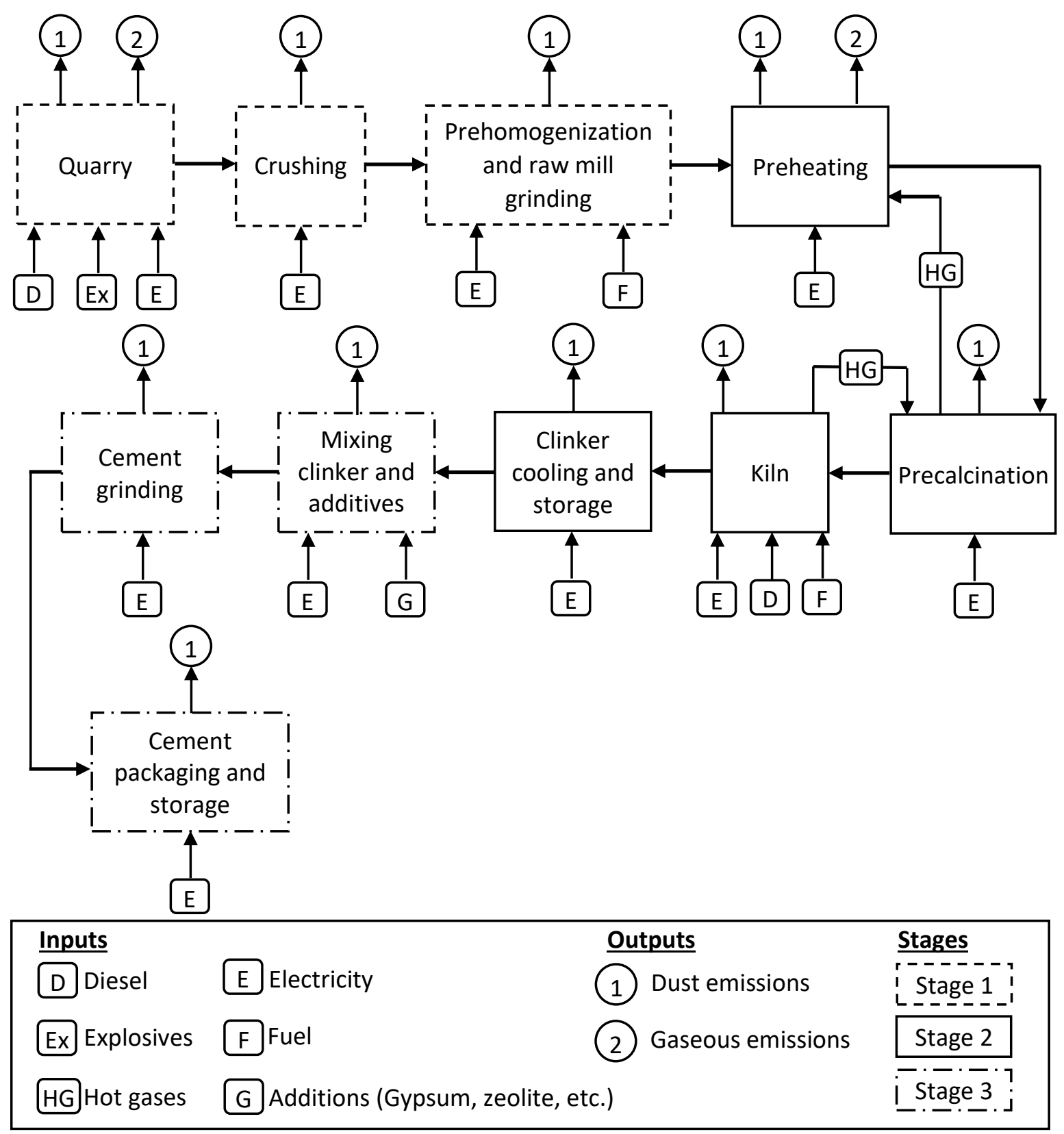


Fig. 9. Process flow diagram of cement production.

a PC $⿴ 囗 ⿱ 一 一)-35 \square$ PP-25

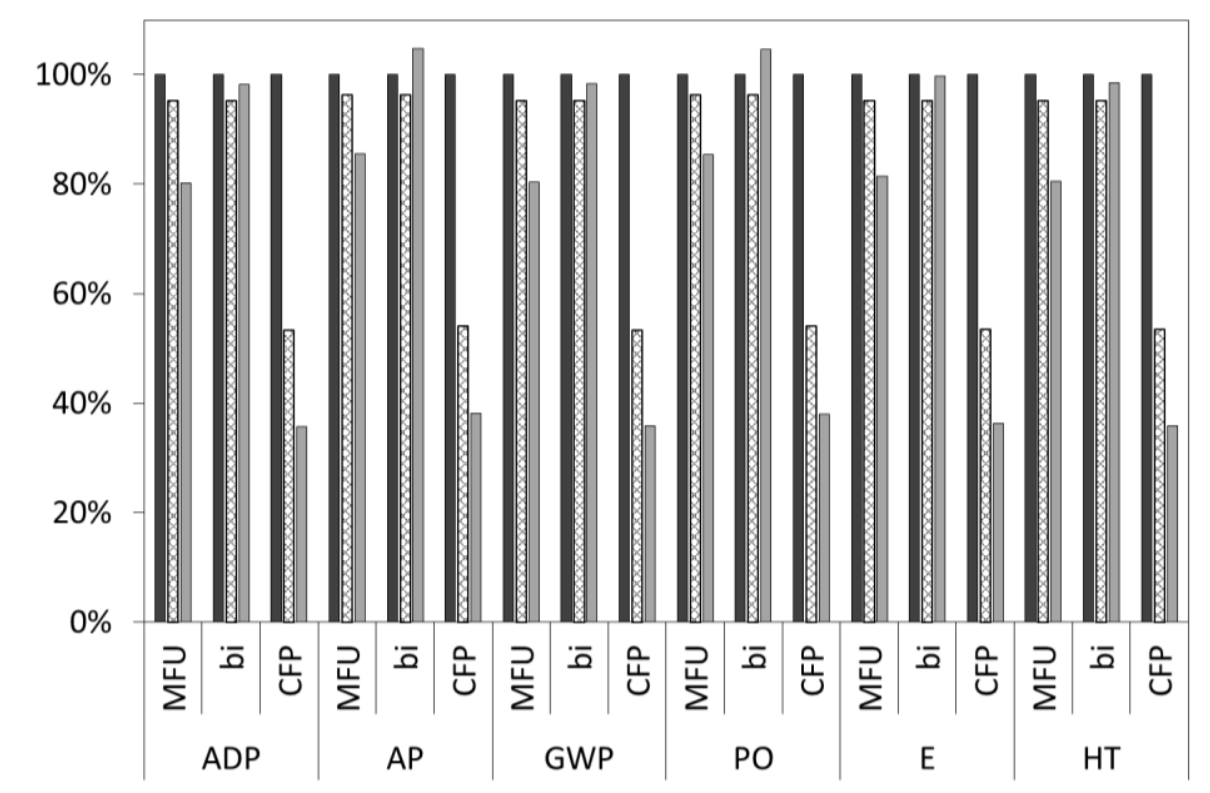

Fig. 10. Comparison of the LCIA results obtained for MFU, bi and CFP 
$\square$ Petcoke $\square$ Electricty $\square$ NOx $\otimes$ SOx 園 CO2 $\square \mathrm{CO}$ 田Dioxins and Furans

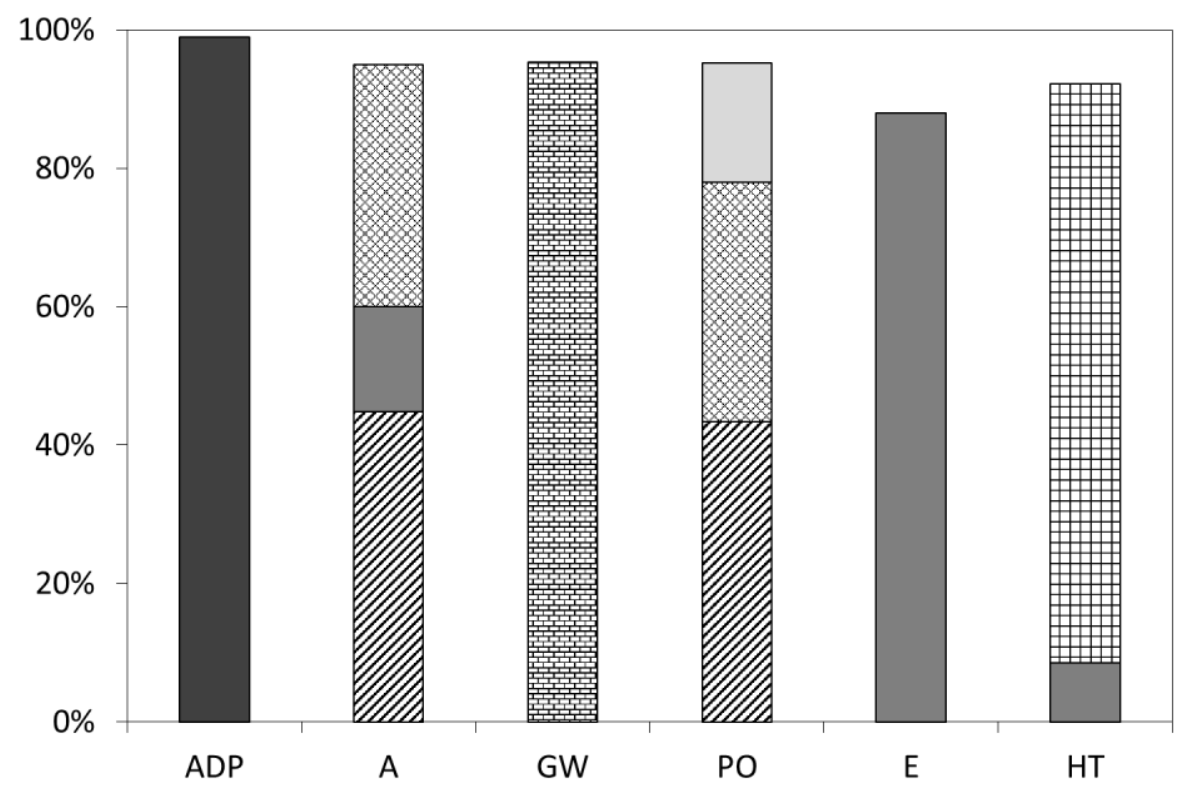

Fig. 11. Influence of inputs/emissions to the different impact categories for PC 


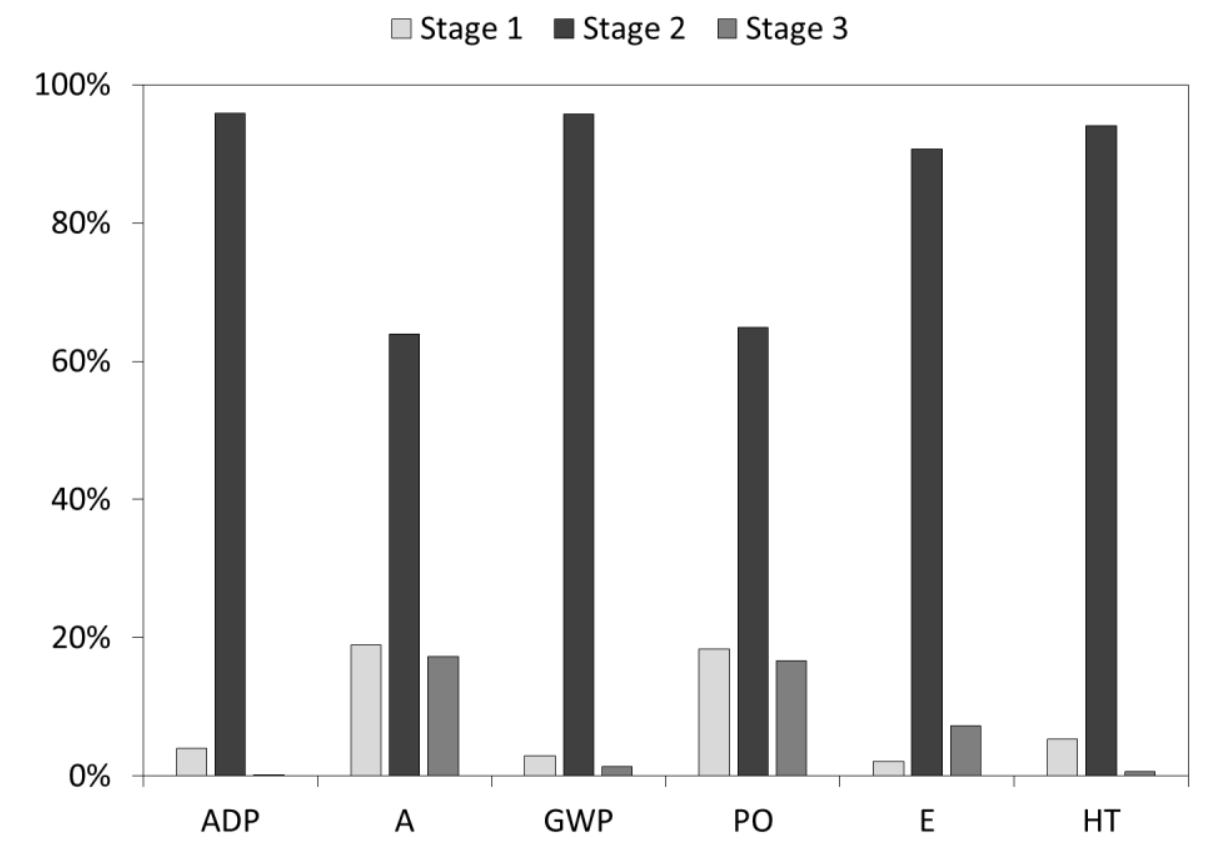

Fig. 12. Contribution of the cement production stages to each impact category (PC). 
Table 10. LCA studies of cement production

\begin{tabular}{|c|c|c|c|c|}
\hline Aim & Boundaries & $\begin{array}{c}\text { Functional } \\
\text { Unit (FU) }\end{array}$ & Highlights & Reference \\
\hline $\begin{array}{l}\text { Compare the life cycle } \\
\text { inventories ( } \mathrm{LCl}) \text { of cement } \\
\text { production in the European } \\
\text { Union }\end{array}$ & $\begin{array}{l}\text { Cradle-to- } \\
\text { gate }\end{array}$ & $1 \mathrm{~kg}_{\text {cement }}$ & $\begin{array}{l}\text { - Clinker production is the main source of GHG. } \\
\text { - Potential benefits of using alternative cementing materials to } \\
\text { replace clinker, alternative fuels and of upgrading } \\
\text { technologies are discussed. }\end{array}$ & Josa et al., 2004 \\
\hline $\begin{array}{l}\text { Compare the impact assessment } \\
\text { of the LCls discussed in Josa et } \\
\text { al., } 2004\end{array}$ & $\begin{array}{l}\text { Cradle-to- } \\
\text { gate }\end{array}$ & $1 \mathrm{~kg}_{\text {cement }}$ & $\begin{array}{l}\text { - } \mathrm{CO}_{2} \text { accounts for over } 98 \% \text { of the GHG emitted. } \\
\text { - The environmental impacts of cement mainly depends on its } \\
\text { clinker fraction. } \\
\text { - The impacts on GWP, A, E and WS are mainly allocated within } \\
\text { the cement plants, while the impact on PO is likely allocated } \\
\text { to outside the cement plants. }\end{array}$ & Josa et al., 2007 \\
\hline $\begin{array}{l}\text { Evaluate the potential to } \\
\text { minimize environmental } \\
\text { impacts by increasing the use of } \\
\text { industrial by-products and } \\
\text { wastes as raw materials, fuel } \\
\text { and cement additives. }\end{array}$ & $\begin{array}{l}\text { Cradle-to- } \\
\text { gate }\end{array}$ & $1 t_{\text {cement }}$ & $\begin{array}{l}\text { - Replacing clinker in the cement mix by recovered materials } \\
\text { reduces more } \mathrm{CO}_{2} \text { emissions than replacing limestone in the } \\
\text { raw meal. } \\
\text { - Increasing the use of recovered material and wastes has } \\
\text { different consequences depending on whether these are } \\
\text { used in the fuel mix, the cement mix or the raw meal mix. }\end{array}$ & $\begin{array}{l}\text { Gabel and } \\
\text { Tillman, } 2005\end{array}$ \\
\hline $\begin{array}{l}\text { Assess the use of waste volcanic } \\
\text { soil after its use to remove } \\
\text { metals from wastewater as a } \\
\text { substitute of limestone for } \\
\text { clinker production }\end{array}$ & $\begin{array}{l}\text { Gate-to- } \\
\text { gate }\end{array}$ & $1 t_{\text {clinker }}$ & $\begin{array}{l}\text { - Using waste volcanic soil reduces the environmental impacts } \\
\text { of cement production. } \\
\text { - Clinker production accounts for most impacts on ecosystem } \\
\text { quality. }\end{array}$ & Navia et al., 2006 \\
\hline $\begin{array}{l}\text { Compare the environmental } \\
\text { performance of } 4 \text { different } \\
\text { cements }\end{array}$ & $\begin{array}{l}\text { Cradle-to- } \\
\text { gate }\end{array}$ & $1 \mathrm{~kg}_{\text {cement }}$ & $\begin{array}{l}\text { - Blended cement (BC) accounts for around } 75 \% \text { of the impacts } \\
\text { of other cements. } \\
\text { - Environmental impacts are proportional to the clinker } \\
\text { content. } \\
\text { - The increased use of pozzolans impacts the strength and } \\
\text { durability of cements. }\end{array}$ & $\begin{array}{l}\text { Huntzinger and } \\
\text { Eatmon, } 2009\end{array}$ \\
\hline
\end{tabular}




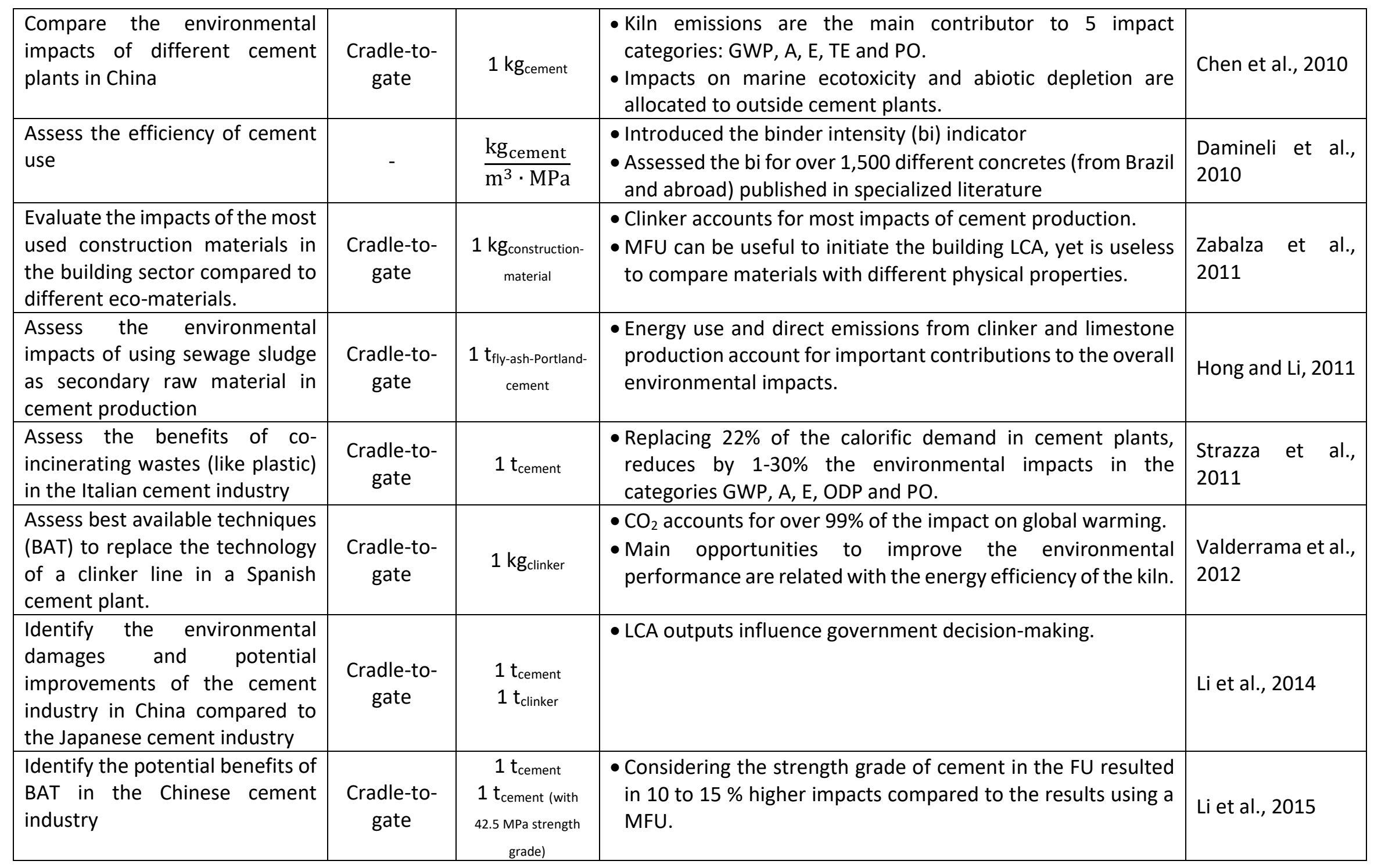




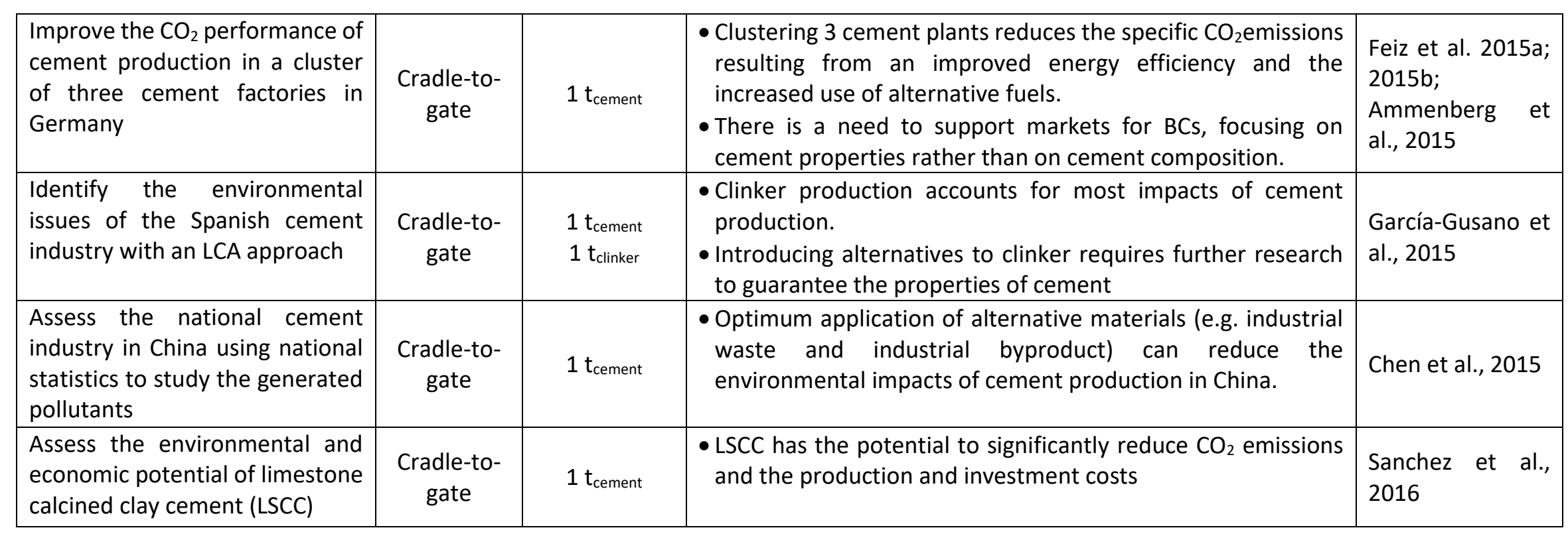


Table 11. Chloride diffusivity of concretes with a varying \% of zeolite for $w / b=0.4$ (Valipuor et al., 2013a).

\begin{tabular}{|c|c|}
\hline $\begin{array}{c}\text { Zeolite } \\
(\%)\end{array}$ & $\begin{array}{c}\text { Diffusivity } \\
D_{\text {ref }} \\
\left(10^{12} \mathrm{~m}^{2} / \mathrm{s}\right)\end{array}$ \\
\hline 0 & 10.00 \\
\hline 10 & 3.94 \\
\hline 20 & 3.78 \\
\hline 30 & 3.22 \\
\hline
\end{tabular}

Table 12. Chloride penetration and diffusivity of concretes with zeolite

\begin{tabular}{|c|c|c|c|c|c|c|c|c|}
\hline \multirow{2}{*}{$\begin{array}{c}\text { Zeolite } \\
\text { (\%) }\end{array}$} & \multicolumn{2}{|c|}{28 (days) } & \multicolumn{2}{|c|}{90 (days) } & \multicolumn{2}{|c|}{180 (days) } & \multicolumn{2}{|c|}{270 (days) } \\
\hline & $\begin{array}{c}\text { RCPT } \\
\text { (C) }\end{array}$ & $\begin{array}{l}D \cdot 10^{12} \\
\left(\mathrm{~m}^{2} / \mathrm{s}\right)\end{array}$ & $\begin{array}{c}\text { RCPT } \\
\text { (C) }\end{array}$ & $\begin{array}{l}D \cdot 10^{12} \\
\left(\mathrm{~m}^{2} / \mathrm{s}\right)\end{array}$ & $\begin{array}{c}\text { RCPT } \\
\text { (C) }\end{array}$ & $\begin{array}{l}D \cdot 10^{12} \\
\left(\mathrm{~m}^{2} / \mathrm{s}\right)\end{array}$ & $\begin{array}{c}\text { RCPT } \\
\text { (C) }\end{array}$ & $\begin{array}{l}D \cdot 10^{12} \\
\left(\mathrm{~m}^{2} / \mathrm{s}\right)\end{array}$ \\
\hline 10 & 2.548 & 7.64 & 1.478 & 4.43 & 1.352 & 4.06 & 1.193 & 3.58 \\
\hline 20 & 1.791 & 5.37 & 775 & 2.33 & 672 & 2.02 & 532 & 1.60 \\
\hline 25 & 1.415 & 4.25 & 646 & 1.94 & 372 & 1.12 & 346 & 1.04 \\
\hline 30 & 1.102 & 3.31 & 419 & 1.26 & 294 & 0.88 & 227 & 0.68 \\
\hline
\end{tabular}

Table 13. $m$ value for concretes with different zeolite fractions

\begin{tabular}{|c|c|c|c|}
\hline Mix & $\mathbf{Z}$ (\%) & $\mathbf{m}$ & $\mathbf{R}^{\mathbf{2}}$ \\
\hline $\mathbf{Z 1 0}$ & 10 & 0.33 & 0.95 \\
\hline $\mathbf{Z 2 0}$ & 20 & 0.52 & 0.96 \\
\hline $\mathbf{Z 2 5}$ & 25 & 0.65 & 0.99 \\
\hline $\mathbf{Z 3 0}$ & 30 & 0.69 & 0.99 \\
\hline
\end{tabular}

Table 14. Characteristics of cements produced in "Cementos Cienfuegos S.A" (Galvez, 2012; Lafont, 2016)

\begin{tabular}{|l|l|r|r|}
\hline Cement & \multicolumn{1}{|c|}{ Standard } & $\begin{array}{c}\text { SG* } \\
\text { (MPa) }\end{array}$ & $\begin{array}{l}\text { Zeolite } \\
\text { (\%) }\end{array}$ \\
\hline PC & ASTM C150, 2016 & 35 & 0 \\
\hline P-35 & Cuban Standard NC-95, 2011 & 35 & 5 \\
\hline PP-25 & Cuban Standard NC-96, 2011 & 25 & 19 \\
\hline
\end{tabular}

*SG: strength grade of cement

Table 15. Design of concrete mix

\begin{tabular}{|c|c|c|c|c|c|c|c|}
\hline $\begin{array}{c}\text { Concrete } \\
\text { mix }\end{array}$ & $\begin{array}{l}\text { Type of } \\
\text { cement in } \\
\text { the mix }\end{array}$ & $\begin{array}{c}\text { Compressive } \\
\text { strength } \\
\text { (Mpa) }\end{array}$ & $w / b^{*}$ & $\begin{array}{c}\text { Binder } \\
(\mathrm{kg})\end{array}$ & $\begin{array}{c}D_{\text {ref }} \times 10^{-12} \\
\left(\mathrm{~m}^{2} / \mathrm{s}\right)\end{array}$ & $\mathrm{m}$ & $\begin{array}{c}\text { Durability } \\
\text { (years) }\end{array}$ \\
\hline 1 & PC & 35 & 0.44 & 400 & 10.00 & 0.20 & 36.4 \\
\hline 2 & P-35 & 35 & 0.44 & 400 & 4.99 & 0.27 & 64.9 \\
\hline 3 & PP-25 & 25 & 0.46 & 350 & 3.53 & 0.50 & 100.0 \\
\hline
\end{tabular}

$* \mathrm{w} / \mathrm{b}$ : water to binder ratio 
Table 16. MFU, bi and CPF for the different cements

\begin{tabular}{|l|r|r|r|}
\hline Cement & \multicolumn{1}{|c|}{$\begin{array}{c}\text { MFU } \\
\left(\mathrm{kg}_{\text {cement }}\right)\end{array}$} & $\begin{array}{c}\text { bi } \\
\left(\frac{\mathrm{kg}_{\text {cement }}}{\mathrm{MPa}}\right)\end{array}$ & $\begin{array}{c}\text { CFP } \\
\left(\frac{\mathrm{kg}}{\mathrm{MPa} \cdot \text { year }}\right)\end{array}$ \\
\hline PC & 1 & 11.4 & 0.314 \\
\hline P-35 & 1 & 11.4 & 0.176 \\
\hline P-25 & 1 & 14.0 & 0.140 \\
\hline
\end{tabular}

Table 17. Inventory of cement production

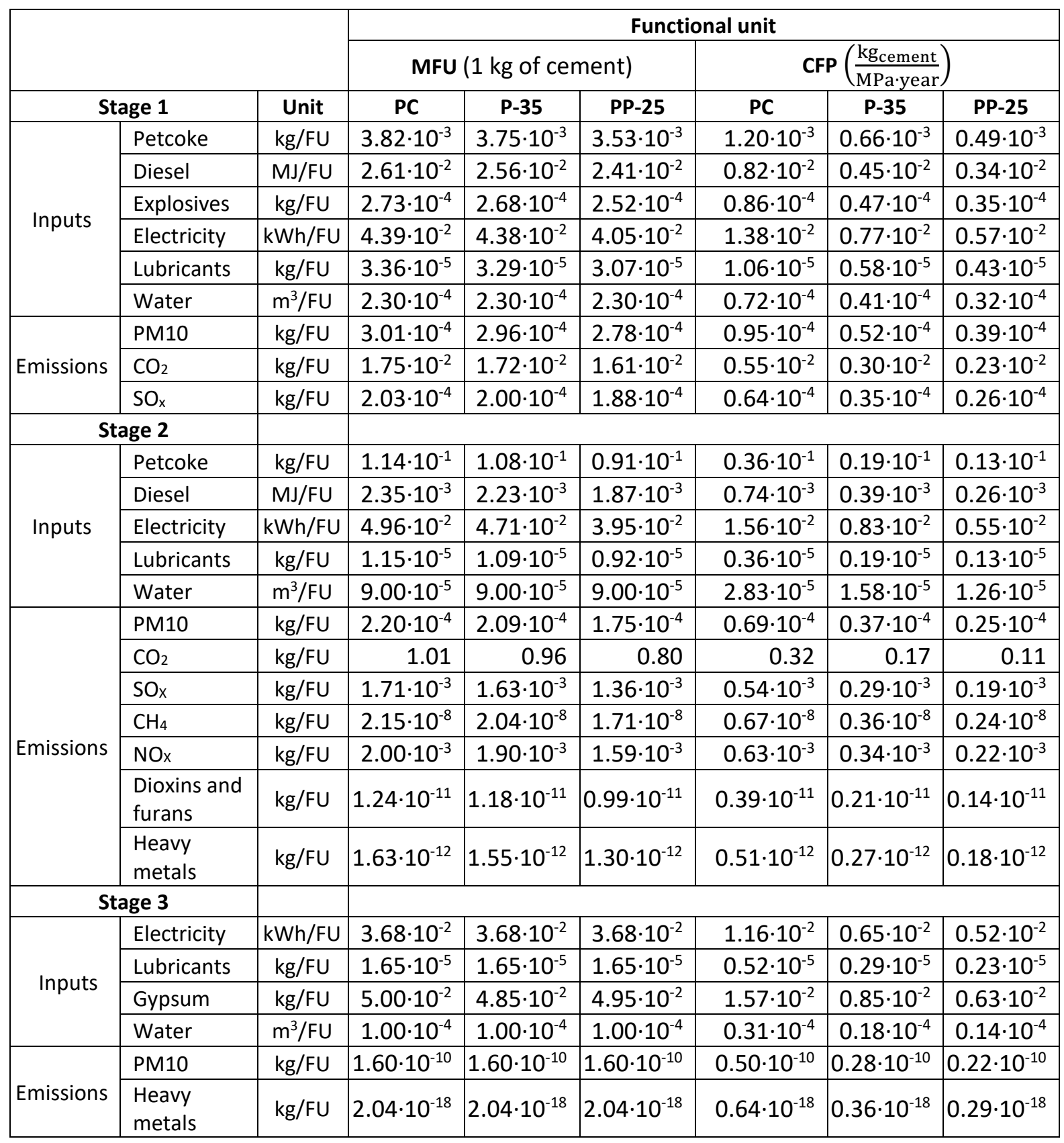


Table 18. LCIA of cement production (per kg of cement)

\begin{tabular}{|l|r|r|r|r|r|r|}
\hline Cement & $\begin{array}{c}\text { ADP } \\
\text { (MJ) }\end{array}$ & $\begin{array}{c}\text { A } \\
\text { (kg-SO2-eq.) }\end{array}$ & $\begin{array}{c}\text { GWP } \\
\text { (kg-CO2-eq.) }\end{array}$ & $\begin{array}{c}\text { PO } \\
\text { (kg-ethylene eq.) }\end{array}$ & $\begin{array}{c}\text { E } \\
\text { (kg-PO4 eq.) }\end{array}$ & $\begin{array}{c}\text { HT } \\
\text { (kg 1.4-DCB eq.) }\end{array}$ \\
\hline PC & 3.8 & $6.56 \cdot 10^{-3}$ & 1.08 & $2.66 \cdot 10^{-4}$ & $0.29 \cdot 10^{-4}$ & $2.8 \cdot 10^{-2}$ \\
\hline P-35 & 3.6 & $6.33 \cdot 10^{-3}$ & 1.02 & $2.56 \cdot 10^{-4}$ & $0.28 \cdot 10^{-4}$ & $2.7 \cdot 10^{-2}$ \\
\hline P-25 & 3.0 & $5.61 \cdot 10^{-3}$ & 0.86 & $2.27 \cdot 10^{-4}$ & $0.24 \cdot 10^{-4}$ & $2.3 \cdot 10^{-2}$ \\
\hline
\end{tabular}

